Đorđe Božović

UDC: $811.163 .41^{\prime} 322.2$

Univerzitet u Beogradu

Filološki fakultet

UDC: 81 '1

DOI: $10.18485 / d h .2015 .2 . c h 14$

\title{
TURINGOV PROBLEM: JEZIČKE TEHNOLOGIJE I LINGVISTIČKA EPISTEMOLOGIJA
}

\begin{abstract}
Sažetak
Kvantitativni i statistički pristupi jeziku i upotreba informacionih tehnologija predstavljaju jednu od okosnica istraživanja u savremenoj lingvistici. Pored implikacija koje statistički pristupi jeziku imaju za teorijsku lingvistiku (npr. u psiholingvistici, leksikologiji i morfologiji, teoriji gramatikalizacije, teorijama usvajanja jezika i sl.), rastuće polje istraživanja predstavlja i tzv. jezičko inženjerstvo, koje obuhvata primenu naprednih informacionih tehnologija i digitalizaciju jezičkih podataka u korpusnoj i računarskoj lingvistici, sintezi govora, mašinskom prevođenju i dr., ali i mašinskom učenju i veštačkoj inteligenciji uopšte. U ovome poslednjem, kao ključno epistemološko pitanje u radu predstavljamo Turingov problem, nazvan po Turingovom testu za procenu inteligentnog ponašanja računara, a koji se zasniva na jezičkom ponašanju sličnom ljudskom.
\end{abstract}

Ključne reči: Al, Alan Turing, John Searle, lingvistička epistemologija.

Govoreći o jezičkom znanju kao predmetu lingvističkih istraživanja, Chomsky (1986) iznosi dva glasovita gnoseološka problema, koja se tiču međuodnosa saznanja i raspoloživog iskustva - tzv. Platonov i Orwellov problem:

The first is the problem of explaining how we can know so much given that we have such limited evidence. The second is the problem of explaining how we can know so little, given that we have so much evidence. (Chomsky 1986: xxv)

Rad na digitalizaciji jezičkih podataka i računarskoj obradi prirodnog jezika omogućio je empirijsku proveru ovih i sličnih glotognoseoloških problema na velikim korpusima i uz pomoć naprednih jezičkih tehnologija za, između ostalog, percepciju i sintezu govora, analizu jezičkih podataka 
i mašinsko prevođenje. Računar opskrbljen odgovarajućom tehnologijom u stanju je da donekle razume ljudski govor i da obavlja jednostavnije lingvističke naredbe, da prepozna strukturu složenog jezičkog znaka, kao i da prevodi s jednog jezika na drugi - uzev u obzir sve njegove nesavršenosti, računar je, dakle, u stanju da obavlja lingvističke funkcije skoro jednako kao i čovek, ili barem da ih vrlo verodostojno simulira.

Ipak, računar se, za razliku od čoveka, gotovo nikada ne suočava sa Platonovim i Orwellovim problemom - njegovo je znanje, makar kako izgleda, gotovo uvek ekvivalentno raspoloživim podacima i inputu kome je izložen. Rad u oblasti veštačke inteligencije zasniva se upravo na takvom, idealizovanom a-računaru koji je definisao Turing (1936). Pitanje da li takva Turingova mašina može i da misli, spoznaje i donosi odluke, tj. da li poseduje svest kao i čovek opskrbljen umom, ultimativno je, u ovome teorijskom okviru, i neodgovorivo. Dok Platonov i Orwellov problem kod ljudi na fenomenološkoj ravni ujedno i dokazuju da čovek ima i svest, kvantitativno i kvalitativno drugačiju od samog raspoloživog iskustva, Turingov računar, koji se nikada ne suočava s ovim problemima, ne može ni na manifestativnom nivou da dokaže, uprkos veštinama i saznanjima kojima raspolaže, da je inteligentan i svestan.

Turing (1950), međutim, na ovo pitanje odgovara svojim poznatim testom za procenu inteligentnog ponašanja računara. Ako čovek, u igri imitacije, nije u stanju da sa sigurnošću raspozna odgovore računara od odgovora drugog čoveka, prinuđeni smo da zaključimo da je računar u stanju da se inteligentno ponaša kao čovek. Jasno je da inteligencija nije shvaćena ovde kao imanentna kognitivna kategorija, već kao dispozicija određenog ponašanja ili barem njegova simulacija, o kojoj sud u Turingovom testu u konačnici daju dispozicije druge osobe, sasvim nalik Quineovom konceptu radikalnog prevođenja u naturalizovanoj epistemologiji i teoriji značenja (cf., e.g., Quine 1960). Više je nego očigledan opšti bihejvioristički kontekst i u koncepciji klasične Turingove mašine i u Turingovom testu (cf. Block 1981).

Searle (1980) daje klasični protivargument računskoj teoriji uma i Turingovom testu. Reč je misaonom eksperimentu tzv. kineske sobe pretpostavimo da Turingova mašina uspe da simulira ljudsko jezičko ponašanje, tako što je opskrbljena sistemom pravila za prevođenje jednog 
formalnog sistema (npr. engleskog) u drugi (npr. kineski). Sve i da jeste u stanju da u potpunosti dekodira jedan i prevede ga u drugi formalni sistem notacije, tako da i Turingovim testom izvorni govornici kineskoga na kraju nisu u mogućnosti da razaznaju mašinske iskaze od ljudskih, to ne znači da računar zaista i razume bilo engleski, bilo kineski jezik. Zamislimo da je Searle zatvoren u sobu, odakle nema nikakvog kontakta sa drugim ljudima u spoljašnjoj sredini, i da odatle rukuje algoritmima za prevođenje simbola engleskog jezika koji služe kao input simbolima kineskog koje tako proizvodi. Searle bi bio u stanju da to uradi pomoću ovog mašinskog sistema pravila i proizvodio bi, iz sobe, iskaze kineskog jezika koji su razumljivi govornicima kineskoga, simulirajući tako inteligentnu komunikaciju, ali to ne bi značilo da i Searle, koji štaviše i jest čovek, a ne računar, tako da nesumnjivo ima svest, zapravo razume kineski, kao ni da zaista komunicira sa govornicima kineskog - Searle, kako ističe, zapravo ne razume ni reči kineskoga (Searle, ibid.: 418).

Stoga je, po Searleu, neodrživ koncept mašinske svesti ili inteligencije („„̌̌rste Al“), jer svest i nije računski sistem, već ljudska biološka karakteristika. Svest postoji zahvaljujući mozgu, čiji ju biohemijski procesi materijalno uzrokuju, kao što su biohemijski uzrokovani i drugi prirodni procesi, poput laktacije ili fotosinteze - ne možemo računarskom simulacijom proizvesti svest, kao što ne možemo računarskom simulacijom formalnih sekvenci u laktaciji ili fotosintezi proizvesti mleko i šećer (Searle, ibid.: 424). Samo mašine i jesu, prema Searleu, u stanju da misle, tj. da imaju svest, i mozak jeste jedna takva specifična biohemijska mašina, ali to nije slučaj i s pozicijom „čvrste Al“, jer se ona upravo, po vlastitoj definiciji, i ne bavi mašinama, nego programima. Mozak jeste, kao takva biološka mašina, u stanju da misli, kao i druge mašine koje imaju jednake kauzalne sposobnosti poput mozga. Dualizam tela i duha, na kome se zasnivaju i računska teorija svesti i Al, međutim, gubi iz vida materijalne uzroke svesti, koji se ne razlikuju suštinski od materijalne uzročenosti mleka ili šećera (Searle, ibid.).

U osnovi Searleovog argumenta kineske sobe leži, dakle, suštinski lingvističko pitanje - problem značenja. Programi kakve proizvodi Al nisu u stanju da misle, tj. da imaju svest ili inteligenciju, iako su u stanju da proizvode formalno gramatične iskaze, zato što ne poseduju intencionalnost 
koja je karakteristika svesti, a temeljno je obeležje semantike ljudskog jezika (v. i Searle 2002). Programi su, naime, samo sistemi formalnih (sintaktičkih) operacija, dok je duh i značenjski sadržajan. Budući da semantika nije svodiva na sintaksu, tj. sintaksa sama nije i dovoljan uslov za proizvodnju značenja, to ni programi nisu nužan i dovoljan uslov za inteligenciju (cf. Searle 1990). U središtu je Searleove lingvističke teorije uma, dakle, jedan drugi konceptualni rascep - između sintakse i semantike, dualizam forme i značenja.

Mada Searle (1980: 419-420) lako odbacuje sistemski pristup značenju, izvesno je da je uspostavljanje značenja sistemski proces, i sâm praktički uslovljen formalnom strukturom i interakcijom elemenata u sistemu. Za Searlea, značenje i razumevanje ostaju bilo u pojedincu koji upravlja programom u kineskoj sobi, bilo u računaru koji je programiran da formalistički prevodi simbole (i u oba slučaja izostaju). Čini se, međutim, naivnim stajalište da Searle, koji operiše formalnim programom za dekodiranje i proizvodnju niski simbola na kineskome, sa uputstvima na njemu razumljivom jeziku, engleskom, ne bi uspeo i da stekne određeni nivo razumevanja kineskoga nakon izvesnog vremena provedenog $u$ radu sa programom. Searleov je argument zasnovan na internalističkom pristupu značenju i vulgarno je materijalistički, jer ne uzima u obzir značenje kao dijalektičku, diskurzivnu materijalnu praksu (v. Marxovu treću tezu o Feuerbachu; cf. i Marković 1961). Naime, kako ističe Block (1980), mašinsko učenje jest znatno složeniji proces nego što ga vidi Searle, koji se odvija upravo u interakciji čoveka i računara. Da bi se uopšte mogla programirati Searleova kineska soba, nužno je i da postoji razumevanje kineskoga koje je kodirano u algoritmima, a koje programerka prenosi računaru. Prema Blocku, Searle bi na to odgovorio da razumevanje i dalje poseduje programerka, a ne i računar. Ali, njeno je razumevanje sada i u njenom sistemu pravila, koji i računar sledi. Niko, tvrdi Block (ibid.: 424), ne zastupa autonomiju računara.

Upravo, neodržive su značenjske teorije koje polaze od autonomije pojedinca. Searle polazi od solipsističkog aksioma da čovek po sebi ima, dok računar nema svest (Searle, ibid.: 421-422). Turing (ibid.: 445-447), međutim, odbacuje taj subjektivistički argument, ističući da, ako značenje jeste nedokučivo za sve druge osim za samog sebe, u komunikaciji s dru- 
gim ljudima uvek držimo sagovornicu inteligentnom, jer njene intencije ili unutrašnje dispozicije i ne možemo doznati. Zato uspostavljanje značenja i jeste tek proizvod društvene interakcije ili interakcije svih elemenata u sistemu, makar ne nužno shvaćene bihejvioristički (cf. i Austin 1980 o problemu tuđih svesti).

Otuda možemo formulirati i Turingov problem kao temeljni epistemološki problem - kako uopšte znamo da znamo? Razumevanje je tek posledica delovanja sistema u celini, bilo zatvorene Turingove mašine koja sledi zadati algoritam, bilo Searleove kineske sobe koja je u stanju da komunicira na kineskom, iako njeni pojedinačni elementi ne razumeju kineski. Ovaj problem, postavljen lingvistički, predstavlja i temeljno pitanje funkcionisanja ljudskog jezika - kako se uopšte uspostavlja značenje u jeziku, kada svaki njegov element, uzet pojedinačno, ne poseduje značenje? To je i ključni Saussureov problem - elementi u jeziku imaju vrednost samo u sistemu (langue), ali jezik kao sistem jeste apstraktan fenomen, koji se uvek realizuje samo kao govor (parole). Ljudi se ne sporazumevaju pomoću apstraktnog jezika kao sistema, već govorom. Ono čemu jesmo izloženi, kao i Searleov operater u kineskoj sobi, jeste sistem formalnih, sintaktičkih pravila za manipulaciju simbolima, koji po sebi nisu nužan i dovoljan uslov za konstituisanje značenja. Ne samo što Searleov operater, zatvoren u kineskoj sobi, ne razume niske simbola na kineskom koje proizvodi - on ne zna ni da li su to zaista značenjski sadržajne niske simbola, iako operiše sistemom pravila za njihovo konstruisanje, bez reakcije druge osobe koja te niske interpretira spolja. Turingov problem, tako, nužno vodi u paradoks.

S druge strane, skorašnji teorijski uvidi digitalne humanistike pružaju mogućnosti i za drugačije konceptualizacije spoznaje i bivstva u interakciji čoveka i računara. Premda se tzv. digitalni preokret (engl. digital turn) u dosadašnjim istraživanjima uglavnom tiče čovekovog iskustva u interakciji s tehnologijom - (de/re)konstrukcije identiteta, participacije i koncepata privatnosti i javnosti (cf. Luppicini 2013; Runnel et al. 2013), digitalne i tzv. nove pismenosti (cf. Mills 2010), komunikacije posredstvom računara (cf. Androutsopoulos 2006; Herring et al. 2013) i dr., kao i njihove primene u različitim profesionalnim domenima - u računarskim naukama interakcija čoveka i računara podrazumeva i reevaluaciju i rekonceptualizaciju same 
tehnologije, uzimajući u obzir računar u interakciji sa čovekom. Iz suštinske sinergije čoveka i mašine, zapravo, proizilaze i praktička rešenja Turingovog lingvističkoga i epistemološkoga problema svesti. Ako je računar u stanju da govori i da razume govor, da manipulira jezičkim podacima i da prevodi, on to čini samo zato što je tako programiran da odgovara na određeni čovekov input i reakciju, i obratno, dakle zato što postoji (obostrana) volja da se komunicira (cf. poziciju koju je, na sličan način, nagovestila Haraway 1985; 1991).

Komunikacija između ljudi, kao ni između čoveka i računara, prema tome, nije stvar internalizovanih predispozicija, kao u Searleovoj materijalističkoj teoriji značenja, u skladu s kojima je onda uspostavljen i formalni kombinatorički sistem simbola (sintaksa), već njegov praktički materijalistički proizvod. Prema Searleu, ljudi se koriste raspoloživom semantikom kako bi manipulisali sintaktičkim pravilima u cilju formiranja razumljivih poruka. Prema Al i računskoj teoriji duha, međutim, ljudi (i računari) koriste se raspoloživom sintaksom s ciljem formiranja razumljivih poruka, kako bi manipulisali semantičkim sadržajima i, na taj način, praktički menjali stvarnost. Budući da razumevanje i uspostavljanje značenja jeste, pre svega, vrsta praktičke delatnosti, kojom se menjaju date materijalne okolnosti, a ne vrsta biološkog determinizma, mora se odbaciti Searleov dualizam forme i značenja, koji i vodi Turingovom paradoksu, u korist praktičke teorije značenja.

\section{Literatura}

Androutsopoulos, Jannis, ed. Journal of Sociolinguistics. Special Issue: ComputerMediated Communication. 10.4 (2006).

Austin, John. „Tuđe svesti“. Svest i saznanje. Ur. Aleksandar Pavković. Beograd: Nolit, 1980. 141-184.

Block, Ned. "Psychologism and Behaviourism". The Philosophical Review 90.1 (1981): 5-43.

Block, Ned. "Searle's Argument Is Just a Set of Chinese Symbols". Behavioral and Brain Sciences 3.3 (1980): 424-425.

Chomsky, Noam. Knowledge of Language: Its Nature, Origins, and Use. Westport, CT: Praeger, 1986.

Haraway, Donna. “Manifesto for Cyborgs: Science, Technology, and Socialist Feminism in 
the 1980". Socialist Review 80 (1985): 65-108.

Haraway, Donna. Simians, Cyborgs and Women: The Reinvention of Nature. London and New York: Routledge, 1991.

Herring, Susan et al., eds. Pragmatics of Computer-Mediated Communication. Berlin: De Gruyter Mouton, 2013.

Luppicini, Rocci, ed. Handbook of Research on Technoself: Identity in a Technological Society. IGI Global, 2013.

Marković, Mihailo. Dijalektička teorija značenja. Beograd: Nolit, 1961.

Mills, Kathy Ann. "A Review of the 'Digital Turn' in the New Literacy Studies" Review of Educational Research 80.2 (2010): 246-271.

Quine, Willard Van Orman. Word and Object. Cambridge, MA: MIT Press, 1960.

Runnel, Pille et al., eds. The Digital Turn: User's Practices and Cultural Transformations. Frankfurt am Main: Peter Lang, 2013.

Searle, John. "Is the Brain's Mind a Computer Program?" Scientific American 262.1 (1990): 26-31.

Searle, John. "Minds, Brains and Programs". Behavioral and Brain Sciences 3.3 (1980): 417-457.

Searle, John. Consciousness and Language. Cambridge: Cambridge University Press, 2002.

Turing, Alan. "Computing Machinery and Intelligence". Mind 59.236 (1950): 433-460.

Turing, Alan. "On Computable Numbers, with an Application to the Entscheidungs problem". Proceedings of the London Mathematical Society 2.42 (1936): 230-265.

\section{Đorđe Božović}

University of Belgrade

Faculty of Philology

\section{THE TURING'S PROBLEM: LANGUAGE TECHNOLOGY AND LINGUISTIC EPISTEMOLOGY}

\section{Summary}

Quantitative and statistical approaches to language and use of the information technology represent some of the main research frameworks in contemporary linguistics. Alongside the implications statistical approaches to language have in theoretical 
linguistics (e.g. in psycholinguistics, lexicology and morphology, the grammaticalization theory, language acquisition theories etc.), a growing field of research also encompasses the so-called linguistic engineering, including the application of advanced information technology and the digitalization of linguistic data in corpus linguistics and computational linguistics, speech synthesis, machine translation etc., as well as in machine learning and artificial intelligence. Concerning the latter, in this paper we pose the Turing's problem as the main epistemological issue, named after the Turing test for evaluating a machine's intelligent behaviour, based on its human-like linguistic behaviour.

Key words: Al, Alan Turing, John Searle, linguistic epistemology. 